Article

\title{
Lack of Participatory Effort: On the Ethics of Communicating Urban Planning
}

\author{
Gunnar Sandin \\ Department of Architecture and Built Environment, Lund University, 22100 Lund, Sweden; \\ E-Mail: gunnar.sandin@arkitektur.Ith.se
}

Submitted: 6 July 2020 | Accepted: 30 September 2020 | Published: 12 November 2020

\begin{abstract}
In all planning processes, including those we label participatory, there are neglected parties. Even when co-produced decisions, equity objectives, or common initiatives are at hand, some actors are likely to be less listened to, or they are never even recognised, hence, 'perfect' participation does not exist. Nevertheless, participatory objectives continue to be an important resilience factor in attempts to make-and architectonically shape-new built environments, based as much in concerned parties' wishes and knowledge of local circumstances, as in the repertoire of traditional professional solutions and political or profit-driven exploitation. This article makes a sample survey on land-use oriented planning and its capacity to include concerned parties, ranging from total neglect of residents to formalised government-steered participation and more spontaneous or insurgent community-driven attempts to communicate a wish. Two basic questions with ethical implications are here raised concerning how planning communication is grounded: Who is invited into dialogue, and what kind of flaws in the establishment of communicational links can be found? These questions are discussed here as examples of ethical dilemmas in planning concerning previously analysed cases in Sweden with an initial reflection also on known cases in India, Germany and Australia. Communicational mechanisms such as 'dialogic reciprocity' and 'successive translational steps' are especially discussed as areas of possible improvement in participatory practices.
\end{abstract}

\section{Keywords}

architecture; citizen participation; dialogic communication; land use; public consultation

\section{Issue}

This article is part of the issue "Built Environment, Ethics and Everyday Life" edited by Mattias Kärrholm (Lund University, Sweden) and Sandra Kopljar (Lund University, Sweden).

(C) 2020 by the author; licensee Cogitatio (Lisbon, Portugal). This article is licensed under a Creative Commons Attribution 4.0 International License (CC BY).

\section{The Ethics of Citizen Participation: An Issue of Democracy and Communication}

Related to modes of participation, ethical issues have been raised as part of the planning discourse at least since Arnstein (1969) presented explicit modalities of the possibilities for real involvement of citizens in planning. The ethical issues have in recent decades concerned, for instance, equity, as a main factor of urban justice, in some cases prioritised (Fainstein \& Fainstein, 2013) before two other fundamental societal principles, namely diversity and democracy. While 'equity' is primarily grounded in an economical world view, another road can be seen as based primarily on diversity, or rather, on the public production of identity (Butler, 2011). When it comes explicitly to urban planning, stakeholder (or participant) authority has been part of the ethics of communicational relations with citizens (Hillier, 2007) ever since dialogue became more significant for strategic planning to acknowledge (Healey, 1992). A basic issue in the domain we call citizen participation is authorisation, or the mechanisms deciding who can actually contribute to the plan-making and the realisation of built environment. This issue has been historically linked to early pragmatist declarations on, and critique of, democracy models that require some "omnicompetence" (Lippman, 1925) of the individual citizen, as well as to later architectural theory, addressing the notion of "expertise" as what not only architects and planners possess, but what citizens know from experience about the situated renewal of 
cities and buildings (Till, 2009). In a broad democratic view on who has the right to have a voice, and in legalised forms of public reviews, a resident does not, of course, have to claim to be an expert to be able to express a right to the place where one lives. However, as a remedy to one-sided presentation and organisation of ideas to build or alter environments, basic democratic ideals need to be actualised, sometimes even when there are good intentions concerning the involvement of citizens. In consideration of the informalities that appear in all organisations (Roy, 2009), and the often inexorable still invisible economical global forces that affect all parts of the world on a daily basis, we could, in defence of certain basic ethical decency, at least try and detect flaws in what is normally believed to be, or accepted as, sound enough planning. In a broad geopolitical and historical perspective, the most common attitude towards local residents or concerned citizens is perhaps not that they are actively overruled or fought against, or considered as insurgent troublemakers, but that they, or their homes, are simply regarded as irrelevant in the lines of production, systematically ignored as "unintended" (Sen, 2007) or "unrecognised" (Sassen, 2002).

Planning, as well as the architectural part of it, thus presents a basic ethical dilemma since it is mostly done by someone for someone else, and therefore contains a judgment both of the part who is supposed to receive the result of the planning but also indirectly of those not thought of as recipients. To state plans or architectures for a future is by default an uneven communicational relation, in itself a process that raises ethical issues related to the risk of producing unwanted otherness (Butler, 2011) or subalterity (Spivak, 1988).

Lead democratic virtues, such as 'openness' and 'transparency,' are generally seen as qualities worth striving for in dialogue, not least in the demanding practice and slack pace of practised planning dialogue, but even those virtues can at times be hard to defend as ethically correct in the sense that they can be used offensively and cynically by strong actors (Žižek, 2006), and that there is no guarantee that the following of these virtues will not, in the end, hurt others-people(s), places, organisms. Such paradoxes can be part of the ethical complexity of the contexts of ordinary planning processes, not least when it comes to the acts of communication in planning and about who, and how, to include in dialogue. Since the practice of communicating future ideas, and ideals, is an inevitable element in all land-use proposals, a particular focus is here devoted to mechanisms and flaws in planning dialogue. This is done by briefly addressing a series of cases with varying types of citizen involvement, and lack thereof, while reflecting on the communicational ingredients and flaws that appear.

\subsection{Participation and Models of Democracy}

In cases where citizens do have an influence-ranging from the legal rights to have a say in different formalised stages of alterations, to the co-design projects where citizens are actively invited to express a wish, but also in cases when they take activist or deliberative initiatives on their own terms-participation becomes an issue strongly related to the fundaments of democratic processes. The differences in belief regarding how much people can actually participate is an old debate, linked for example to the early modern attempts at forming democratic ideals and systems. In The Phantom Public, Walter Lippman (1925) saw a problem with the then prevailing democratic models in the sense that he feared that they brought an overestimation of individuals' agentic possibilities as political beings, and he related this problem to three flaws in the idealistic image of citizens' opportunities: lack of omnicompetence; lack of time; and lack of operational structure. These flaws are still to a significant degree valid in contemporary planning, where citizens cannot always be expected to have the capacity to take an active part (Parker, 2014).

More than Lippman (1925), his contemporary John Dewey (both of them historically regarded as pragmatists) saw in The Public and Its Problems (Dewey, 1925) the enabling of education and common decision-making as a possible way forward. This more idealist and supposedly 'altruist' pragmatic view is also still pertaining to certain models of democracy, some of which are nationally situated, like the so-called 'Swedish model' of social democracy (Rojas, 1991). Sweden and the other Scandinavian countries have been acknowledged for having maintained a certain stability as regards the relation between government, private capital and citizens, thus establishing a 'third way' of solidarity and democratic commonness that has gained recognition as important in inclusive modes of planning (Fainstein \& Fainstein, 2013, p. 45) and for direct citizen involvement in planning and design (Albrechts, 2004; Gregory, 2003). The democratic instruments and trust-building of this tradition can, however, be disputed (Åström, 2020; Kraff, 2018), partly as a consequence, as we will see here, of how communicational aspects are not sufficiently considered.

\subsection{On the Communicational Pragmatics of Participatory Planning}

In today's urban planning, roughly three decades after what Healey (1992) recognised as a communicative and collaborative turn in planning and planning theory, we see-albeit only partially if we judge from the large scale and uniform type of buildings that are being erected all over the world-a larger acceptance among architects of the increased political complexity, or the messier reality, that constitutes contemporary societies. Even if participation itself is often still considered a threat to designing firms, politicians and financiers alike, and their freedom to realise projects within reasonable time frames or pursue complex and spatially intriguing architectural results (Miessen, 2010), a recent shift into acknowledging more social factors and lived environments comes in a way 
also as a late, but straightforward 'response' to Lippman, namely that omnicompetence, or expertise, is not necessarily the same as disciplinary skill, or all-round education, but a "situated knowledge" (Haraway, 1988). Awan, Schneider, and Till (2011) present a vast range of built projects illustrating the feature of architectural professionalism (pp. 43-51) that acknowledges residents, local users and clients, as the ones that possess much of the straightforward knowledge and situated expertise needed.

At times, shortcomings in participation, reminding of the Lippmanian flaws of democracy, namely that citizens would not be competent or willing enough to participate, can be used inversely to fuel projects aiming at pursuing expertise-training activities (Claesson, 2014), projects that might need 'protected arenas' (Cameron \& Grant-Smith, 2005) to strengthen the agency of locals as preparation before formalised processes to come.

Recent decades, not least in Sweden (Tahvilzadeh, 2015), have shown a proliferation of official and semiofficial (partly private) participatory initiatives, such as so-called participatory governance arrangements, as part of municipalities' will to increase communities' or districts' influence in politics, often with elements of situated design initiatives, some of which do activate communities in new ways, but some being pursued more cynically with an upholding of already established power relations, making no essential difference in the local context (Tahvilzadeh, 2015; Taylor, 2007). However, there are also recent examples of participatory arrangements of co-design, where a certain self-criticism is made on the initiating part (Björgvinsson \& Keshavarz, 2020), raising overarching questions about the political consequences of relation-building between initiating and part-taking subjects (Sandström, 2019). Expectations on participatory projects can at times be quite high but are not seldom lowered in the end, pragmatically reduced to, for instance, recognition of mutual learning about a situation (Lenskjold \& Olander, 2020), or perhaps to detecting previously unknown creative potential (Sandercock \& Attili, 2014).

\section{Urban Planning and the Negligence of Concerned Citizens: A Review of Seven Cases}

In what follows, seven briefly reviewed cases will highlight the ethical issue of recognition of citizens in planning. The range of cases covers varying existential urgency in different parts of the world and different types of governmental involvement. Four of the cases are located in Malmö, in the southern part of Sweden, thus representing a Swedish 'culture' of citizen involvement. A particular focus in the following reflections on the seven cases is kept on communicational flaws or unevenness.

\subsection{Informal Planning: Not on the Map in Calcutta}

When the architect, activist and social theorist Jai Sen started to take an interest in the developments of East
Calcutta in 1975, he found that settlers in an area of nearly two million people would be affected by massive redevelopment (Sen, 2007) and the people he happened to meet there as a professional advisor of residents and service organisations, had "not even heard of" the larger redevelopment project (Sen, 2007, p. 19). As a response to this situation, Sen initiated the Unintended City Project, which developed into a five-year-long undertaking of research and public education, intending to make communities that were threatened by eviction speak for their rights regarding sanitation services, ration cards, postal delivery, voting rights, etc. At the time, ration cards served, besides giving access to food and daily necessities, as an address index, issued and acknowledged by the government, thus having the additional effects of both being an identity document for its beholder, and providing the possibility to receive postal letters. Sen coined the term "unintended city" to name those areas of a habitat that did not exist at all on formal maps, using the epithet 'unintended' also for the communities and people in Calcutta whose existence and labour was "used by formal economic, planning and governance structures...that had no real place for them" (Sen, 2007, p. 17).

Sen's mapping of these areas, which took several years to execute by his group Unnyan (consisting of voluntary planners and architects), had some impact on local politics and policy, in the sense that for a limited period (1984-1989) "the incidence of evictions decreased, the incidence of militant resistance increased, and there was some dialogue" (Sen, 2007, p. 22). The dialogic channel for the population living along the bodies of water in the area slowly emerged, due to the spontaneously emerged spokesperson agency initiated by Sen, enabling certain recognition, and helped to facilitate connections to new roads, etc. The remaining effect was however limited, according to Sen (2007) himself, who regrets in retrospect that he did not pursue a type of mapping engaging more deeply with the people, suggesting that such interaction would have strengthened a vocabulary of their own, and stand a possibility to live on through memory and culture, in ways that the mapping effort by Sen and his group in itself could not do. What the Unnyan project-and other similar voluntary, activist or insurgent practices in the world-indicates, is the endurance needed to uphold a resilient communicational culture, and that the creation of channels of communication through a mutually understood language (such as the visual language of maps) is needed if any actual results of change are to be expected. The case also shows that acts of communication implicate acts of 'successive translation,' in the sense that there are several stages in translational acts (Sonesson, 2014) and when such acts include more than one semiotic resource (like writing and maps) the dialogic chains will include mechanisms like translation/presentation/ re-translation/interpretation, etc., i.e., chains, each part of which deserves attention. 
The lack of communication from the authorities, as reported by Sen, corresponds with how Ananya Roy (2009) describes the governmentalist informalities in the planning of Calcutta, and elsewhere in India, extending in principal to a global context as well. Roy $(2004 b, 2009)$ attributes informal planning not, as often is the case, only to alternativist initiatives, but to the official planning authorities that give themselves the right to act without a formal anchoring in transparent or legally grounded procedures.

\subsection{Critical Participation and Tactical Media: The Renewal of Tempelhofer Feld in Berlin}

After the closing of the airport area Tempelhofer Feld in Berlin 2008, possibilities opened up to new ideas for the future of this vast and centrally located land. Apart from the suggestions and competitions for the area launched by the governmental body (Berlin Senate Department of Development and the Environment) proposing urban housing, there were also several local ideas about letting this area remain more or less an open green area, with the addition of locally-run urban farming, leisureoriented activities and small service-oriented businesses (Schalk, Šušteršič, \& Sandin, 2018). In this case, traditional instruments of planning were mixed with informal participatory processes, but also insurgent initiatives criticising the governmentally sanctioned forms of participation for being used strategically to reach alreadydecided objectives. Temporary activities and businesses were established before this area suddenly became objected to hold up to 7,000 of the large incoming group $(80,000)$ of Syrian refugees to Berlin in 2015 , demanded by Berlin Senate (Schalk et al., 2018, p. 305). At most, the old hangar hosted 2,500 refugees in a very large open indoor space, with a poor sound environment, etc. The unhealthy conditions led to the partial relocation of refugees to other (temporary or more stable) residential units (Beck, Noack, \& Sohyun Lee, 2018). The larger Tempelhofer Park green area project has established itself as protected from further exploitation close to the borders, as a result of a direct democracy vote in 2014. Some of the spontaneously emerged critical groups then engaged in alternative participatory formats, pursuing education about the area, and teaching visitors about Nazi crime history, through "walks, lectures, readings and open conversations with former forced labourers and eyewitnesses" (Schalk et al., 2018, p. 308). That way, some of the originally insurgent movements could find a working model in the renewed environment in what Schalk et al. (2018) call "historical reworking" (p. 313) as a particular mode of critical participation. The original engagement in land use as protection of recreational qualities thus turned into a continuous running of new modes of service-oriented communicational channels.

\subsection{Ignorance of Culture by Development of Land: Hindmarsh Island and the Difficulty to Speak}

Another example of planning authorities' disregard of residents' grounds is that of Kumarangk or Hindmarsh Island in Australia. Starting as a proposal to connect an island with a bridge to provide further development, the case transformed by the turn of the century into a seminal example in the history of Aboriginal rights to land vs official federal law's statements regarding property rights (van Krieken, 2011). As a consequence of the planning decisions taken, the case through the years came to include vast additional legal processes, ending with the approval of the official plan to let the bridge be built. The case caused a rift of opinion in Australia, and the depriving of land use for Indigenous people, especially that of Ngarrindjeri women. Accusations (to a significant extent held in court) were made about people fabricating grounds for their rights, and officials taking a side in the conflict were accused, and convicted, for violating the rules of management of these affairs (Hillier, 2007, pp. 88-89; van Krieken, 2011). The dialogue, or rather flaws in the basic dialogic contract that surrounded the case, led to reconsiderations of laws and procedural matters regarding land rights, while also triggering research on the solidity of administrative law to protect or align with interests in land and land use (van Krieken, 2011). Jean Hillier (2007) took in Stretching Beyond the Horizon this geopolitical case of planning, and part of recent Australian land-use history, to reflect on some of the philosophical and practical fundaments of planning as well as on the communicational contract that regulates planning. Hillier (2007) states that what "counted as 'legitimate' knowledge," in this case represented by official planning authorities and legal procedures "excluded competing truth claims as deviant" (p. 85), and van Krieken (2011) points out that: "Rules governing considerations [of the interests of Aboriginals] based on a presumption of equality in social, political, and economic relations, rather than from the reality of settler-colonial inequality" (p. 145) tend to produce ineffective legislative attempts, and "Australian law is likely to remain 'whitefella law,' despite the courts' best intention" (p. 146).

Participation, or lack thereof, in this case became a legal court matter and the ethical ground evoked by this example is that the stating of people as 'equal before law' may in certain communicative realities turn out to not even be possible. The dilemma of equality, and equity, here also becomes a matter of the communicational and cultural ground, since what "the power of the 'establishment' has defined...as 'legitimate knowledge'" is partly rooted in the authorities' language and ontological comprehension of 'time' as a linear logic of succession, a logic that supports "capitalist relations of production, where time is money" (Hillier, 2007, p. 85). Hillier's reasoning points out that communication in planning, hence participation in planning that depends on the sharing of communicational codes, suffers from not sufficiently 
considering that cultural differences require a reciprocal building of common code that grounds the participatory negotiations.

\subsection{Participatory Shortcomings in Official Planning in Malmö, Sweden}

The three cases so far rendered, from different cultures in different parts of the world, have actualised ethical dilemmas grounded in what is required of telling and listening, virtually as soon as any planning is at stake. Well aware that some of these cases are directly linked to extreme situations, including brute colonialist and migration effects, we can now, when turning to more democratically negotiated rituals of planning, nevertheless see that communicational acts, and flaws in their realisation, have some common factors bridging such existential gaps (cf. Roy, 2004b). A difference between the Swedish cases that follow, and the previously reviewed Indian, German and Australian examples, is that we now (still only briefly) turn to examples where ethical issues arise more as part of (omitted) legal rights to participate. This turn towards less extreme situations and more into the everyday business of official planning does however not, as we shall see, exclude cases of direct ethical concern, such as the eviction of people, or prohibition from established cultural habits. So even if the discussion of these four following cases is in a way reflecting less severe conflictual situations if seen in a global perspective, they show general elements of controversy and neglect of cultures and perspectives (Roy, 2004b). Another reason for bringing this totality of cases together in one study is to at least indicate through examples that today we cannot avoid a global connection between political forces on earth, where migration and ecological issues are of common concern and Sweden or Scandinavia are, of course, no exception here, struggling as other regions with acknowledging its position in current states of global affairs.

The way communicational acts are prepared, constructed and pursued in several and unpredictable steps, is of crucial importance in any type of citizen inclusion act. Such acts include successive translation of ideas from one context to another, and at times from one media to another, which implies that the dialogue requires a double act of translation: from the initiating party's thoughts to a relevant presentation, and from that presentation to interpreting parties. Hence, 'communication' does not only mean what Healey (1992) once saw as a general 'turn' in the practices and discipline of planning (and planning theory) but in a more direct semiotic sense addresses the mechanisms that define the everyday apparatus of what ought to be part of the dialogue. As we now turn to a contemporary Swedish context, participation is (again) reflected through examining forces of decision-making and the presence of informality in official planning procedures and how they tie to the intended right for citizens to have a voice. The examples brought up in what follows are four planning cases in Malmö, a city located in the southernmost region of Sweden, connected to Denmark via a bridge (Figure 1).

\subsubsection{Malmö Hyllie}

The City of Malmö officially announced in 2002 that 2.5 million SEK would be invested to evaluate the possibility of establishing an amusement park with the theme 'Scandinavia' (Sandin, 2019). Three American consultants specialising in themed experience design in large-scale urban format were invited to work in conjunction with local initiators and visionaries who saw a theme park as a well-found future item of development in this Scandinavian region. The park was planned to be located on agrarian soil close to the Öresund transnational Bridge leading to Copenhagen in Denmark (Figure 1).

The park was estimated to open in 2014. A rough visual rendering of the planned area appeared in the local public newspaper Sydsvenskan (2008) showing an amusement area located south of the dense part of the city, carrying a set of attractions in a style reminiscent of cartoonist fantasy worlds (Sandin, 2019). The years went by, and as the financing and management of the future park remained an unresolved issue, the project had to be terminated in 2013 and disappeared from Malmö's official planning agenda.

The visionaries and politicians that were involved became the only clear local stakeholders throughout the 10 years of the project's duration, developing what Metzger (2013) calls 'stakeholderness,' by which a stakeholder is successively created, educated and solidified. Here, in this case, stakeholderness was developed in secret discussions between Swedish visionaries and American consultants (Sandin, 2019), winding up presenting Scandinavia in concept documents mainly through clichés of ancient Nordic history and mythology, but also through the consultants' model of market-oriented 'visitor education' and conventional adventure park aesthetics (Malmö Stad, 2002). The plans were not deliberated or productively tested in conjunction with possible concerned local publics and parties. Consequently, living cultural (Scandinavian) values were ignored, not least in the visionary design production, values that could have more concretely provided the soughtafter educational and popular content (Sandin, 2019). This unfortunate authoritarian and "biased" (Healey, 2007) mode of planning became not only an act of prioritising commercial rules before the experiences of people, but one of ignoring the values of local culture. The extreme confinement of interpretational minds became a weakness of the project as a whole that struck back, possibly contributing to the failure in the end (Sandin, 2019).

\subsubsection{Malmö Slussplan}

In 2012, a new 12-storey building was erected as part of the renewal of a square in Malmö, Sweden. During the 


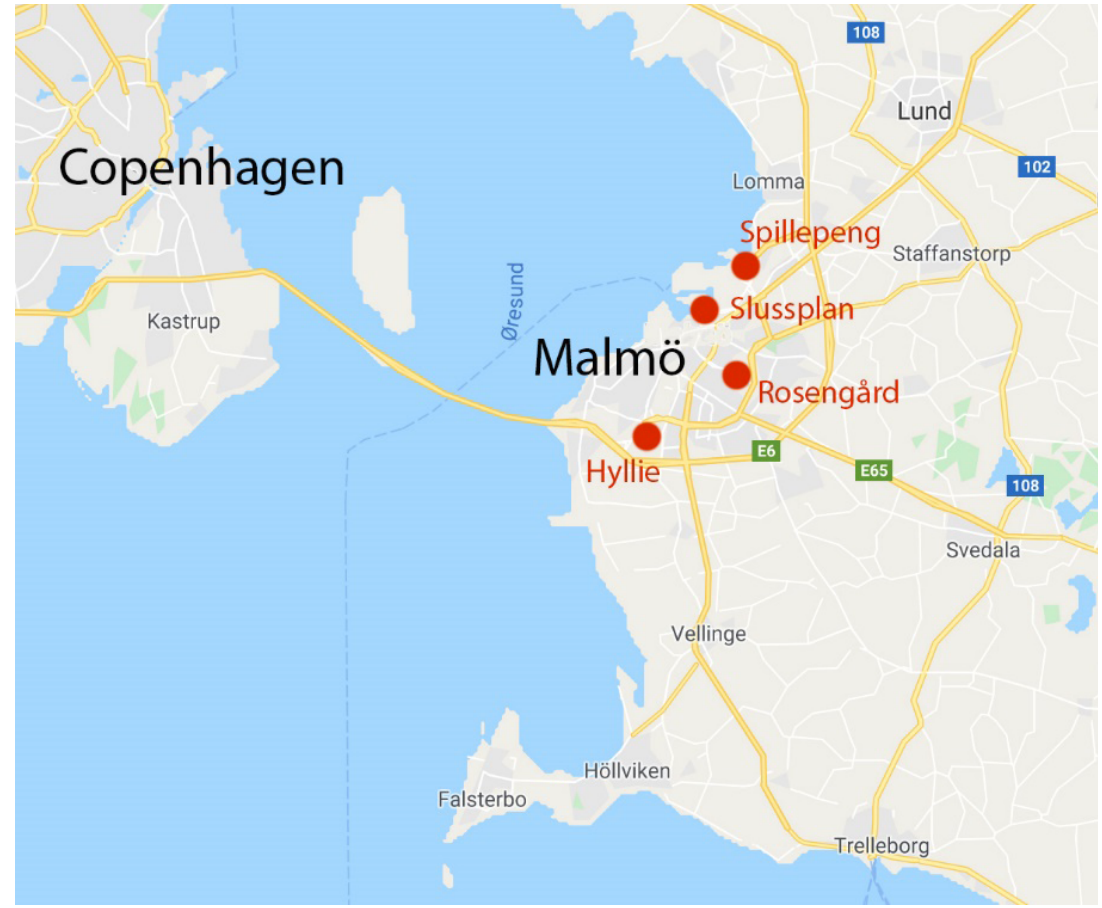

Figure 1. The location of four planning cases in Malmö. Source: Adapted from Google Maps (n.d.).

slow progression of this renewal, from the first presentation of ideas in 2002 until the erection of the building, there was a lack of interest from the major authorisers in listening to what types of place-specific needs and activities could have contributed to this act of urban renewal (Sandin, 2015). An unusually large number of answers, 330 in all, expressed various reactions: to the height of the building, its location concerning traffic, and its function as turning a public place into a house with private ownership of apartments. Occupiers of the only remaining one-storey building were evicted from the area, some of these groups (an Iranian association) left on request, others (homeless) were evicted with police assistance (Sandin, 2015).

The large number of written protests reveals that several protesters came from a solid economical group, owners or renters of neighbouring apartments, the values of which they assumingly wanted to protect. These citizens were speaking with a certain measure of authority, capable of formulating quite elaborate reflections, referring for example to EU law. But there were also protesters less familiar with how to raise a voice, and some of these could join temporally formed associations writing straight-forward responses in the public review. Finally, some homeless people resided in the area without formal address, people that had no voice at all, left unrecognised by authorities as well as neighbours, and in the end, faced with eviction.

In the phase when the building contractor expected a building permit, the only existing single-story brick building was demolished. Thereafter, the square was fenced off in various ways, for example, to protect an occasional soil-quality test, or to accommodate containers filled with equipment for future grounding of the new building. The fenced protection of the area, lasting for approximately four years, was made through spatial and material obstruction, communicating to the public that this is no longer their local area. This long-lasting obstruction was in practice maintained through occasional digging activities, through containers placed in the square for significant periods, or through repelling enclosures with signposts and boards showing the names of constructors, excavation firms and building consultants (Sandin, 2015). In one end of the area, a well-used shortcut was physically obstructed by large blocks of stone. These examples of materials possessing delegated agency (Latour, 2005), in connection with the strategic use of delays caused by waiting for decisions and economical solutions, had the effect that protests slowly faded away, and after a couple of years, the municipality could also pursue a break of the original promise and plan to provide rentable apartments, changing them instead into condominiums (Sandin, 2015). The visual renderings of the area showed in the first phases of the project a low enough building to be accepted, while in the second part, after the permission to build, the building's height was instead emphasised in the images to give the impression of an urban landmark, a high-rise offering apartments with a view (Sandin, 2018, p. 324).

In planning procedures like these, where the municipality and individual civil servants have the authorised and delegated right to read and summarise voices, there is room for selective manoeuvres in various directions. Despite a quite elaborate public response procedure, the totality of voices could be treated in the public response either as a unified group or as scattered citizens, depend- 
ing on what type of issue, simply by officials responding to commenters together or one after another. This means that opinions, such as about the height of the building in the Slussplan case, were treated as quite scattered, which disenabled the neighbouring population to "build equivalence" (Purcell, 2008, p. 175) enough as one clear voice. Such a grouped, or ungrouped, selection of addressees escapes the legal frame for what a municipality is obliged to do in terms of communication.

\subsubsection{Malmö Spillepeng}

The third case in Malmö concerns a waste dump area located right at the northern border of Malmö (see Figure 1). This artificially constructed peninsula stretching into the Öresund sea between Sweden and Denmark, was at the time of its realisation, in 1987, subjected to the legally stated public consultation of a detailed plan (see Lomma Kommun, 2008), a plan that was never fully realised, nor did the plan or its revisions cause any public debate (Qviström, 2008). There were initial concerns stated by an environment protection association and also by a neighbouring petroleum-industry that this sudden appearance of a new peninsula would affect wildlife and shore conditions along the coastal line. When a remaking of the original detailed plan was suggested in 2010, the obligatory public consultation review took place. However, this review also silently passed the broad official debate. Such silence is not unusual, especially when the reviews concern regional rather than singular municipal interests (Bjärstig et al., 2017). The general tendency in official participatory planning, namely that people get more concerned the spatially closer the subject matter is, could perhaps today be questioned if we regard later years' raised global environmental awareness, but still, in regional planning procedures, the allocation of resources is not the same for citizen communication as in municipal planning.

The waste material that builds up this landfill is delivered regularly from 14 regionally close municipalities that share ownership in the waste processing facility, a large and technologically advanced incineration plant, named SYSAV. Waste material is imported also from other parts of Sweden and abroad, on a more occasional contractual basis, which means that this facility can also claim to be a facility of national interest, which in itself makes it harder to adjust this area based on local needs. The original detailed plan from 1987 stated a reorientation of land use, to be executed after fulfilled construction of the peninsula, and to be turned into a recreation area, with a marina including sand beaches, harbours for small boats, walking and cycling paths, etc., however, after a period of delays (Sandin, 2008) and later revisions of the plan (Burlöv Kommun, 2011) none of this has actually happened. In the parts closest to the original coastline, some space continued to be allocated to small animal-breeding associations, and a shooting range, with a certain amount of simple land- scaping added for recreation. Instead, Spillepeng continued to function as a major regional dumping ground, with ever more refined end products from incineration. The mechanisms of public participation, in this case, can be characterised as essentially non-existent, since the consultations were handled as communication mainly with other official bodies (Burlöv Kommun, 2011). The collectively owned SYSAV has an on-going obligation to keep the land in shape, and serves also as a 'public window' for the area of Spillepeng and offers rest products for sale. This quite large landscape area constitutes in itself a significant influence in the process of reshaping, which means that scale, rather than people's opinions, becomes a main decisive actor. In the case of Spillepeng, the long omission of the promised recreation area for several of the region's citizens indicates informal handling of formal processes (cf. Roy, 2004a, 2009), partly enforced through the County Administrative Board giving its a signature confirming the pursued review acts. Not only can "a democratically accountable and trusted planning agency...persuade recognised actors in society that change is desirable" (Bjärstig et al., 2017, p. 40), but also support the stance that deviating from a convenient state of affairs is not desirable (Grange, 2017). This case points to the difficulty of establishing a communicational base in inter-municipal circumstances, but also to the ethical dilemma of wanting or not wanting to break the status quo of a stabilised circumstance, suiting some but not others.

\subsubsection{Malmö Rosengård}

The last Malmö-based case is a co-design initiative, made during a period of renewal in Rosengård, a renewal that included a new local train station and the idea of a spectacular high-rise building, but also with the intention of the municipality leadership to engage more in a marginalised part of the city. This district has been stigmatised for a long time, in official and social media in Sweden and elsewhere, as a "ghetto-like area" (Sernhede, 2007, p. 229) emblematic of violence and criminality. A large part of the population are immigrants, and as the assimilation into cultural acknowledgement in Sweden can be quite hard to handle. The district, suffering from a high rate of unemployment, and low medium income, has seldom been taken into account as an area where creative initiatives exist. A co-design project was therefore launched, aimed at improving the mediational facilities for local musicians and music-producers rooted here. This particular co-design project, among others, was run by researchers from Malmö University in cooperation with a media company, with connections also to the City of Malmö, "centred on supporting knowledge-based entrepreneurial work" (Björgvinsson \& Keshavarz, 2020, p. 257). The project also involved Swedish Television and Swedish Radio, the traditional national state-supported broadcasting companies. The project's original intentions were to support young groups from Rosengård to gain 
larger arenas and powerful branch partners. However, in some of the decisive meetings about how to proceed in the project, the researchers and the media company failed to include enough representative mass from the area, which revealed an ontological position where the addressed participants were seen as a unified group in need of participatory support. This omission of real circumstances led to "a rupture in the social fabric of the [already existing music-producing] organisation" (Björgvinsson \& Keshavarz, 2020, p. 256). Some of the initiators in retrospect admitted the presence of unrealistic ideas that led to a virtually non-functional communicational situation and only a superficial presence in the area. The mass and magnitude of this kind of participatory project in Sweden (Tahvilzadeh, 2015), of which Rosengård in Malmö is a typical case, led the media columnist Nabila Abdul Fattah to state that she was "tired of experiment-people who exploit the system for their own profit" (Abdul Fattah, 2014). What Abdul Fattah wished for was not external and artificially established participatory projects, but an inverted form for participation with direct contribution from granters, municipality councils and city districts that would instead support activities already anchored. The researchers Björgvinsson and Keshavarz (2020) suggest that the renowned late 20th century-born Scandinavian participatory design model (cf. Bødker, Grønbæk, \& Kyng, 1993) that have been described as "striving for democracy [and] adopted [and] practised in North America and elsewhere since the mid-1980s" (Gregory, 2003, p. 62) need to reconsider participation, not as a one-sided democratic involvement of citizens, but instead as an active form of "part-taking" based on mutual acceptance of truly agentic parts, hence with contributors that possess more than just the "flat" role of participant (Björgvinsson \& Keshavarz, 2020).

In reflection of the Rosengård example, just as in several of the cases above, we see that an initial communicational intention may get lost in the second phase of the successive translation of ideas, namely the phase where an open interpretation of an initially presented intention is at stake.

\section{Negligence and Recognition of Communicative Mechanisms in Participation}

The seven cases here rendered showed various types of omittance of citizens' voices in planning communication. The cases have ranged from the brute politics of colonialist planning to the daily matters of legally implemented acts of participation. The cases show consequences of, or indications of, what Healey (2007) regards as "communicative bias," or what Sandercock and Attili (2014) calls "reduction to dependency status." Even for the cases where participatory aspects follow the law, they may, as we have seen, have unwanted effects and can, from a working participation point of view, risk becoming nothing but counterproductive, either for (the community of) citizens or for the planning authority itself. We have seen how participation must be created and grounded in local engagement, often over several years, where the initiator represents a community through grounded work and adequate media (such as the maps to build local agency in Calcutta, and the public walks and history lectures as critical participation in Tempelhofer Feld, Berlin).

A less successful attempt at mediating local culture was made through the support of music production in Rosengård, Malmö) with not enough local anchoring. These media-related projects had to lower their original ambitions, and existed without any guarantee of success, but reached at least partial results as regards learning, acknowledgement and implementation. We have seen how the large-scale eviction of people led to activation (of established squatters in Calcutta, of representatives of regular cultural usage of land at Hindmarsh Island, and critical participatory actions in Tempelhofer Feld). These cases showed both persistent and enduring self-conducted participatory action concerning official bodies or as voluntary planning initiatives. In the cases of formally invited participation (Malmö-Slussplan, Malmö-Spillepeng, and as a co-design project, Malmö-Rosengård) we could see that fulfilling the invitations to public review or officially supported participation arrangements, does not guarantee actual involvement, but rather reveals problems that must be dealt with as regards the informal distribution of delegated planning (to civil servants), but also as regards the points in time when citizens are actually approached. Official authorities' negligence towards publicly transparency despite the legally established routines for that (as in Malmö-Hyllie and Malmö-Spillepeng) were seen as producing long-standing silence among people with a virtual, but not actual right to have a say concerning particularised representational interests, possibly also leading to inaction and nonfulfillment of plans.

In all of these cases, certain non-anchored, or "informal" (Roy, 2009) official values had priority, leading either to the forced raising of public awareness through affected groups and their representatives, or to spontaneously created critical participatory practices. In some cases, such informal handling simply led to unresolved protests or further unnoticed silence. Inter-cultural or financial agreements ignoring a locally anchored culture were seen as not constructive, causing ruptures in existing local communities, or contributing to the failure as projects. Taken together, these cases show that a recurrent challenge is that a participatory act is always based in establishing enough wide and enduring commonness, or 'code' in the communicational act, perhaps needing at least for some time, a closed-off learning space of its own. For participatory acts to have an impact that makes a difference as community building, and avoid being illusory or "manipulative" (Arnstein, 1969), they need to include actual, locally established governance mechanisms over time, in consecutive steps, applied on conditions of those it concerns, not of the initiators. 
In relation to the range of flaws here presentedto be seen also as factors to be dealt with-the ethics of planning has appeared more specifically as reflected in two reappearing semiotic mechanisms, which can be seen as areas to improve in the communication that constitute large parts of participatory projects. They are here stated as recognition of interpretational steps in translational acts and as ensuring dialogic reciprocity with enough actors. One way to deal with both of these mechanisms in practical situations, which should be beneficiary for the planning results and their architectural presence, is to acknowledge and follow the chains of interpretation, for instance by ensuring a listening presence in later translational stages, where the dialogue is successively interpreted and articulated by different parttaking members.

\section{Acknowledgments}

For introducing me to topics, cases, contacts and perspectives that have fed into this article I would like to thank Annelie Nilsson, Cecilia Wendt, Erling Björgvinsson, Lize Mogel, Maria Hellström and Meike Schalk.

\section{Conflict of Interests}

The author declares no conflict of interests.

\section{References}

Abdul Fattah, N. (2014, December 16). Sluta göra oss i förorten till labbråttor [Stop making us in the suburbs into lab rats]. ETC. Retrieved from http://www.etc. se/ledare/sluta-gora-oss-i-fororten-till-labbrattor

Albrechts, L. (2004). Strategic (spatial) planning reexamined. Environment and Planning B: Planning and Design, 31, 743-758.

Arnstein, S. R. (1969). A ladder of citizen participation. Journal of the American Planning Association, 35(4), 216-224.

Åström, J. (2020). Participatory urban planning: What would make planners trust the citizens? Urban Planning, 5(2), 84-93.

Awan, N., Schneider, T., \& Till. J. (2011). Spatial agency: Other ways of doing architecture. London and New York, NY: Routledge.

Beck, L., Noack, R., \& Sohyun Lee, J. (2018, March 7). Inside an enormous abandoned airport in Berlin that's coming back to life. The Washington Post. Retrieved from https://www.washingtonpost.com/ world/inside-an-enormous-abandoned-airport-inberlin-thats-coming-back-to-life/2018/03/16/65ca 90a6-2642-11e8-b79d-f3d931db7f68_story.html

Bjärstig, T., Thellbro, C., Stjernström, O., Svensson, J., Sandström, C., Sandström, P., \& Zachrisson, A. (2017). Between protocol and reality: Swedish municipal comprehensive planning. European Planning Studies, 26(1), 35-54.
Björgvinsson, E., \& Keshavarz, M. (2020). Partitioning vulnerabilities: On the paradoxes of participatory design in the city of Malmö. In A. M. Dancus, M. Hyvönen, \& M. Karlsson (Eds.), Vulnerability in Scandinavian art and culture (pp. 247-266). Cham: Springer.

Bødker, S., Grønbæk, K., \& Kyng, M. (1993). Cooperative design: Techniques and experiences from the Scandinavian scene. In D. Schuler \& A. Namioka (Eds.), Participatory design: Principles and practices (pp. 157-176). Hillsdale, NJ: Lawrence Erlbaum Associates.

Burlöv Kommun. (2011). Detaljplan för Spillepeng, Arlöv 22:188 m fl i Burlöv, Lomma och Malmö kommuner, Skåne län [Detailed plan for Spillepeng, Arlöv 22:188 in Burlöv, Lomma and Malmö]. Burlöv: Burlöv Kommun. Retrieved from https://docplayer.se/docview/ 58/42466408/\#file=/storage/58/42466408/ 42466408.pdf

Butler, J. (2011). Bodies in alliance and the politics of the street, Transversal. Retrieved from http://eipcp.net/ transversal/1011/butler/en

Cameron, J., \& Grant-Smith, D. (2005). Building citizens: Participatory planning practice and a transformative politics of difference. Urban Policy and Research, 32(1), 21-36.

Claesson, R. (2014). Berätta staden tillsammans: Planering som en plats för lärande, lyssnande och konflikt [Telling the city story together: Planning as a place for learning, listening and conflict]. In C. Listerborn, $\mathrm{K}$. Grundström, R Claesson, T. Delshammar, M. Johansson, \& P. Parker (Eds.), Strategier för att hela en delad stad: Samordnad stadsutveckling i Malmö [Strategies to heal a divided city: Coordinated urban development in Malmö] (pp. 99-110). Malmö: Malmö University Publications.

Dewey, J. (1925). The public and its problems. New York, NY: Holt.

Fainstein, S., \& Fainstein, N. (2013). Restoring just outcomes to planning concerns. In N. Carmon \& S. Fainstein (Eds.), Policy, planning and people: Promoting justice in urban development (pp. 32-53). Philadelphia, PA: University of Pennsylvania Press.

Google Maps. (n.d.). Retrieved from https://www. google.com/maps

Grange, K. (2017). Planners: A silenced profession? The politicization of planning and the need for fearless speech. Planning Theory, 16, 275-295.

Gregory, J. (2003). Scandinavian approaches to participatory design. International Journal of Engineering Education, 19(1), 62-74.

Haraway, D. (1988). Situated knowledges: The science question in feminism and the privilege of partial perspective. Feminst Studies, 14(3), 575-599.

Healey, P. (1992). Planning through debate: The communicative turn in planning theory. The Town Planning Review, 62(2), 143-162.

Healey, P. (2007). Urban complexity and spatial strategies: Towards a relational planning for our times. London and New York, NY: Routledge. 
Hillier, J. (2007). Stretching beyond the horizon. A multiplanar theory of spatial planning and governance. Aldershot: Ashgate.

Kraff, H. (2018). Exploring pitfalls of participation. Gothenburg: Art Monitor.

Latour, B. (2005). Reassembling the social: An introduction to actor-network theory. Oxford: Oxford University Press.

Lenskjold, T. U., \& Olander, S. (2020). Ethics in contemporary civic engagements: Toward an ethics of a minor design activism. In L. Scherling \& A. DeRose (Eds.), Ethics in design and communication (pp. 117-124). London: Bloomsbury Collections.

Lippman, W. (1925). The phantom public. New York, NY: Harcourt, Brace and Company.

Lomma Kommun. (2008). Tillägg till stadsplan för Lomma, Lomma Kommun [Addition to city plan for Lomma]. Lomma: Lomma Kommun. Retrieved from https://www.burlov.se/download/18.581344c31742 6cd45b0ac289/1599139241416/137T\%20Ändring \%20och\%20utvidgning\%20av\%20stadsplanen\%20 för\%20Spillepeng.pdf

Malmö Stad. (2002, March 22). Preliminär bedömning av förutsättningar för en temapark i Malmö [Preliminary assessment of prerequisites for a theme park in Malmö] (Report by Economics Research Associates). Malmö: Malmö Stads Arkiv.

Metzger, J. (2013). Placing the stakes: The enactment of territorial stakeholders in planning processes. Environment and Planning A: Economy and Space, 44(4), 781-796.

Miessen, M. (2010). The nightmare of participation. Berlin: Sternberg Press.

Parker, P. (2014). Samproduktion av platser: Former för deltagande i utveckling av mötesplatser längs Rosengårdsstråket. [Co-creation of places: Modes of participation in development of meeting places along the Rosengård passage]. In C. Listerborn, K. Grundström, R Claesson, T. Delshammar, M. Johansson, \& P. Parker (Eds.), Strategier för att hela en delad stad: Samordnad stadsutveckling i Malmö [Strategies to heal a divided city: Coordinated urban development in Malmö] (pp. 63-72). Malmö: Malmö University Publications.

Qviström, M. (2008). A waste of time? On spatial planning and 'wastelands' at the city edge of Malmö (Sweden). Urban Forestry and Urban Greening, 7, 157-169.

Purcell, M. (2008). Recapturing democracy: Neoliberalization and the struggle for alternative urban futures. London: Routledge.

Rojas, M. (1991). The "Swedish model" in historical perspective. Scandinavian Economic History Review, 39(2), 64-74.

Roy, A. (2004a). The gentleman's city. In A. Roy \& N. Al Sayyad (Eds.), Urban informality: Transnational perspectives from the Middle East, Latin America, and South Asia (pp. 147-170). Lanham, MD: Lexington Books.
Roy, A. (2004b). Transnational trespassings: The geopolitics of urban informality. In A. Roy \& N. Al Sayyad (Eds.), Urban informality, transnational perspectives from the Middle East, Latin America, and South Asia (pp. 289-317). Lanham, MD: Lexington Books.

Roy, A. (2009). Why India cannot plan its cities: Informality, insurgence and the idiom of urbanization. Planning Theory, 8(1), 76-87.

Sandercock, L., \& Attili, G. (2014). Changing the lens: Film as action research and therapeutic planning practice. Journal of Planning Education and Research, 34(1), 19-29.

Sandin, G. (2008). Keys to heterotopia. An actantial approach to landfills as societal mirrors. Nordic Journal of Architectural Research: Landscape and Landscape Architecture, 2, 75-87.

Sandin, G. (2015). Temporal agency and the gradual privatization of a public square: The renewal of Slussplan, Malmö. In M. Kärrholm (Ed.), Urban squares: Spatiotemporal studies of design and everyday life in the Öresund region (pp. 87-114). Lund: Nordic Academic Press.

Sandin, G. (2018). Architectural imagineering and the semblance of dialogue. In S. Gromark, J. Mack, \& R. van Toorn (Eds.), Rethinking the social in architecture: Making effects (pp. 298-315). New York, NY and Barcelona: Actar Publishers.

Sandin, G. (2019). The making of "Scandinavia" in the visionary design of a theme park. In A. E. Toft, M. Rönn, \& E. Smith Wergeland (Eds.), Reflecting histories and directing futures: NAF proceedings series 2019-1 (pp. 249-273). Oslo: Nordic Academic Press of Architectural Research.

Sandström, I. (2019). Towards a minor urbanism: Thinking community without unity. Lund: Department of Architecture and Built Environment of Lund University.

Sassen, S. (2002). The repositioning of citizenship: Emergent subjects and spaces for politics, Berkely Journal of Sociology, 46, 4-26.

Schalk, M., Šušteršič, A., \& Sandin, G. (2018). Acting in common: Critical participation in controversial urban development projects. In S. Gromark, J. Mack, \& R. van Toorn (Eds.), Rethinking the social in architecture: Making effects (pp. 298-315). New York, NY and Barcelona: Actar Publishers.

Sen, J. (2007). Other worlds other maps: Mapping the unintended city. In L. Mogel \& A. Bhagat (Eds.), An atlas of radical cartography (pp. 12-27). Los Angeles, CA: Journal of Aesthetics and Protest Press.

Sernhede, O. (2007). Microphone prophets and schooling outside School: The global tribe of hip hop and immigrant youth in 'The New Sweden'. In M. Carlson, A. Rabo, \& F. Gök (Eds.), Education in 'multicultural' societies: Turkish and Swedish perspectives (pp. 227-243). Istanbul: Swedish Research Institute in Istanbul.

Sonesson, G. (2014). Translation and other acts of mean- 
ing: In between cognitive semiotics and semiotics of culture. Cognitive Semiotics, 7(2), 249-280.

Spivak, G. C. (1988). Can the subaltern speak? In C. Nelson \& L. Grossberg (Eds.), Marxism and the interpretation of culture (pp. 271-313). Basingstoke: Palgrave Macmillan.

Tahvilzadeh, N. (2015). Understanding participatory governance arrangements in urban politics: Idealist and cynical perspectives on the politics of citizen dialogues in Göteborg, Sweden. Urban Research \& Practice, 8(2), 238-254.

Taylor, M. (2007). Community participation in the real world: Opportunities and pitfalls in New Governance Spaces. Urban Studies, 44(2), 297-317.

Till, J. (2009). Imperfect ethics. In J. Till (Ed.), Architecture depends (pp. 171-187). Cambridge, MA: MIT Press.

van Krieken, R. (2011). Kumarangk (Hindmarsh Island) and the politics of natural justice under settlercolonialism. Law \& Social Inquiry, 36(1), 125-149.

Žižek, S. (2006, January 27). Jack Bauer and the ethics of urgency. In These Times. Retrieved from https://inthesetimes.com/article/jack-bauer-andthe-ethics-of-urgency

\section{About the Author}

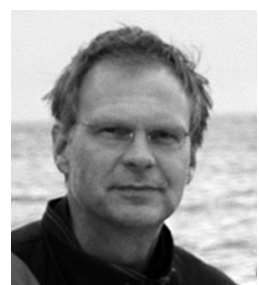

Gunnar Sandin is Associate Professor at the Department of Architecture and Built Environment, Lund University. His research includes studies of architecture and urban development through theories of place, planning and semiotics of space. Publications include: "Democracy on the Margin" in Architectural Theory Review (Routledge, 2013); "Urbanity: The City as the Specifically Human Niche" in Human Lifeworlds (Peter Lang, 2016); and "The Making of 'Scandinavia' in the Visionary Design of a Theme Park" in Reflecting Histories and Directing Futures (NAF 2019-1). 